\title{
Evaluation of Neutrophil/Lymphocyte Ratio Changes Between Pre- and Post-menopausal Life for Cardiovascular Risk Prediction
}

\author{
Kardiyovasküler Risk Tahmini Için Pre- ve Post-menopozal Hayatta Nötrofil/Lenfosit Oranı \\ Değișikliklerinin Değerlendirilmesi
}

\author{
Ahmet Karakurt', Cennet Yıldız \\ ${ }^{1}$ Department of Cardiology, Kafkas University Faculty of Medicine, Kars, Turkey; ${ }^{2}$ Department of Cardiology, Bağcllar Tekden Hospital, \\ İstanbul, Turkey
}

\begin{abstract}
AIM: Neutrophil to lymphocyte ratio (NLR) has demonstrated in various clinical studies to identify the increased atherosclerotic cardiovascular risk. However, the prognostic value of NLR is unknown in healthy postmenopausal women. The aim of this study to evaluate the relationship between and premenopausal and postmenopausal healthy women regarding the NLR.
\end{abstract}

METHODS: The study population included 295 premenopausal (median age 37 years, range 33-42 years) and 153 postmenopausal (median age 56 years, range 52-62 years) healthy women who have admitted cardiology clinic between March 2013 and May 2014. The complete blood count was obtained from all patients. Total leukocytes were counted and differential count obtained for neutrophil, lymphocyte and NLR were evaluated.

RESULTS: There were no significant differences between premenopausal and postmenopausal healthy women regarding NLR (median: 1.77 [interquartil range (IQR): 1.38-2.25], and 1.68 [IQR: 1.24-2.07], $p=0.240$ respectively). Similarly, there were no significant differences between two groups in terms of neutrophil and lymphocyte counts (median: $3.7 \times 103 / \mathrm{mm}^{3}$ [IQR: 3.04-4.50] vs. $3.63 \times 103 / \mathrm{mm}^{3}$ [IQR: 2.79-4.33], $p=0.393$ and 2.12 [IQR: 1.792.52] vs. 2.10 [IQR: 1.70-2.60], $p=0.624$, respectively).

CONCLUSION: This study demonstrated that there is no difference regarding NLR between the premenopausal and healthy postmenopausal women. These findings have also revealed that the NLR, neutrophil and lymphocyte counts do not change in menopausal life, and thus can not be used as a marker for atherosclerosis in these groups.

Key words: neutrophil/lymphocyte ratio; neutrophil; lymphocyte; menopause; cardiovascular risk

Yard. Doç. Dr. Ahmet Karakurt, Kafkas Üniversitesi Tip Fakültesi, Paşa Cavırı, Kars, Türkiye, Tel.047422521 06-9, 4479 Email.karakurt38@hotmail.com Geliş Tarihi: 03.03.2016 • Kabul Tarihi: 27.04.2016
ÖZET

AMAÇ: Birçok klinik çalıșmada nötrofil lenfosit oranının (NLO), artmıș aterosiklerotik kardiyovasküler risk belirlemede prognostik değerinin bilinmesine rağmen, postmenopozal sağlıkı kadınlarda ki pognostik değeri bilinmemektedir. Bu çalıșmanın amacı, premenopozal ve postmenopozal sağlıkı kadınlar arasında NLO değerlendirmektir. YÖNTEM: Mart 2013 ve Mayıs 2014 tarihleri arasında kardiyoloji polikliniğine kontrol maksatı bașvuran ve herhangi bir kardiyak yakınması olmayan premenopozal 295 (ortanca yaș 37 yıl, dağılım 33-42 yıl) ve postmenopozal 153 kadın (ortanca yaș 56 yıl, dağılım 52-62 yıl) çalıșmaya alındı. Tüm hastaların tam kan hücre sayıları kaydedildi. İki grup arasında rutin kan sayım parametreleri nötrofil, lenfosit ve nötrofil lenfost oranı (mutlak nötrofil sayısının ve mutlak lenfosit sayısına oranı) karșılaștırıldı.

BULGULAR: Premenopozal ve postmenopozal sağlıkı kadınlar arasında nötrofil-lenfosit oranı açısından istatistiksel fark saptanmadı (sırasıly median: 1,77 [interquartil range (IQR): 1,38-2,25] ve 1,68 [IQR: 1,24-2,07], $p=0,240)$. Benzer șekilde, lokosit ve lenfosit sayıları arasında da istatistiksel fark saptanmadı (sırasıly, median: 3,7×103/ $\mathrm{mm}^{3}$ [IQR: 3,04-4,50] kr. 3,63×103/mm $\mathrm{mm}^{3}$ [IQR: 2,79-4,33], $p=0,393$ ve 2,12 [IQR: 1,79-2,52] kr. 2,10 [IQR: 1,70-2,60], $p=0,624)$.

SONUÇ: Bu çalıșma, NLO'yu postmenopozal dönem ile premenopozal dönem arasında fark olmadığı göstermiștir. Ayrıca bu sonuçlar, nörofil, lenfosit sayılarının ve NLO'nun postmenopozal dönemde farkllık göstermediğini ve ateroskleroz riski belirteci olarak kullanılılamaz olduğunu ortaya koymuștur.

Anahtar kelimeler: nörofil/lenfosit oranı; nötrofil; lenfosit; menopoz; kardiyovasküler risk

\section{Introduction}

The menopause is the permanent discontinuance of menstruation due to the loss of ovarian follicular activity. Clinically, menopause is diagnosed after twelve months of amenorrhea, so the time of the final menses is determined retrospectively ${ }^{1}$. Loss of ovarian follicular 
function results in decreased circulating estrogen levels. Several studies have shown protective effects of estrogen against atherosclerosis ${ }^{2}$. The incidence of cardiovascular events gradually increases in postmenopausal women, which may be due to increases in risk factors and diminished levels of estrogen ${ }^{3,4}$. Atherosclerotic cardiovascular disease is responsible for approximately one-third of deaths worldwide ${ }^{5}$. Atherosclerosis is a particular form of the systemic chronic low-grade inflammatory process resulting from interactions between humoral, cellular mediators and multiple risk factors ${ }^{6}$. The important role of neutrophils, lymphocytes, monocytes in atherosclerosis has been well established ${ }^{7-11}$. The NLR is used as indicators of systemic inflammation in various conditions. Also, it was suggested that NLR has prognostic value in some atherosclerotic diseases ${ }^{12,13}$.

It is well-known that menopause has unfavorable effects on lipid profile, but its impact on neutrophil, lymphocyte count, and NLR is unknown ${ }^{2,4,14}$. The goal of this study was to determine if there were differences in inflammatory parameters of complete blood count (CBC) regarding the neutrophil, lymphocyte count, and NLR between premenopausal and postmenopausal women and to evaluate whether the NLR could be a predictor of chronic inflammation.

\section{Methods}

This retrospective study included 448 healthy women $(n=448)$ who were admitted to our cardiology clinic between March 2013 and May 2014. These 448 women were divided into two groups, a premenopausal group $(n=295)$ and the postmenopausal group $(n=153)$. All patients were provided informed consent, and the study was approved by the local ethic committee.

Exclusion criteria included the presence of the irregular menstrual cycles, history of hormone replacement therapy (HRT), infection in the last one month, high body temperature $\left(>38^{\circ} \mathrm{C}\right)$, and the history of an inflammatory disease. The patients with a known coronary artery disease, valvular heart disease, history of rhythm disturbances, abnormal electrocardiography (ECG), left ventricular systolic dysfunction, cerebral or peripheral vascular disease, hematological disorders, renal or liver insufficiency, and thyroid dysfunction have also excluded the study.

All subjects were evaluated with physical examination, $\mathrm{CBC}$, routine biochemical examination, ECG and echocardiography (ECHO). Venous blood samples were taken from patients after a 12-hour fasting and analyzed for CBC parameters. The CBC parameters including the white blood count (WBC), hemoglobin $(\mathrm{Hb})$, platelet, mean platelet volume (MPV), neutrophil, and lymphocyte were tested. Also, the biochemical parameters including the total cholesterol (TC), high-density lipoprotein cholesterol (HDL-C), lowdensity lipoprotein cholesterol (LDL-C), triglyceride (TG), and glucose levels were tested. NLR was calculated as the ratio of neutrophil cell count to lymphocyte cell count using COBAS c311 analyzer system (Roche Diagnostics, Germany).

\section{Statistical Analysis}

The Statistical Package for the Social Sciences software (SPSS 20.0 for Windows, Inc., Chicago, IL, USA) was used for all statistical calculations. The KolmogorovSmirnov test was used to determine the distribution of data from continuous variables. Normally distributed data were given as mean \pm standard deviation (SD), data with non-normal distributions were expressed as median, and the interquartil ratio (IQR), and dichotomous data were given as a percent. A significance level of the difference between the premenopausal and postmenopausal group was analyzed using Student-t test for parametric value and MannWhitney $U$ test for not normal distributing variables. Differences between dichotomous variables were evaluated using the $\chi^{2}$ test. Correlations between NLR and various parameters were assessed using Spearman correlation test. Statistical significance was defined as $\mathrm{p}<0.05$.

\section{Results}

The median age of the all study population was 42 years (IQR: $35.25-53$ years). The median age and body mass index (BMI) of premenopausal (37 [IQR 33-42] years, and 25.91 [IQR 22.89-30.83] kg/ $\mathrm{m}^{2}$ ) and postmenopausal (56 [IQR 62-62] years, and 28.47 [IQR $25.87-31.21$ ] $\mathrm{kg} / \mathrm{m}^{2}$ ) women were recorded respectively. Compared with premenopausal women, weight, BMI, Hb, Hct and fasting blood glucose levels were significantly higher in postmenopausal women, whereas mean height and smoking ratio were comparable between two groups. There were no significant differences between two groups with respect to MCV and RDW values. Postmenopausal women showed statistically significant increase in serum TC, TG, LDL-C levels. TC/HDL-C, LDL-C/HDL-C, 
and TG/HDL-C ratio were significantly increased in postmenopausal women as compared to that in premenopausal women. In contrast, HDL-C levels did not show a statistically significant difference between two groups. Clinical and laboratory features of two groups are given in Table 1.

Our study has primarily focused on the effects of menopause on neutrophil, lymphocyte count and NLR in healthy women who do not receive an HRT. The median of NLR were 1.77 (IQR 1.38-2.25) in premenopausal and 1.68 (IQR 1.24-2.07) in postmenopausal women respectively. This difference was not statistically significant $(p=0.24)$. Similarly there were no significant differences between the two groups in terms of neutrophil (median [IQR] $3.7 \times 10^{3} /$ $\mathrm{mm}^{3}$ [30.04-4.50] vs. $3.63 \times 10^{3} / \mathrm{mm}^{3}$ [2.79-4.33], $\mathrm{p}=0.7393)$ and lymphocyte counts $(2.12$ [1.79-2.52] vs. $2.10[1.70-2.60], \mathrm{p}=0.624$, respectively). WBC, $\mathrm{MPV}$ median values, and platelet count were found to be similar between two groups. Hematological parameters and NLR values are given in Table 2.
There were negative correlations between NLR and FBG, Hb, MCHC, RDW, TC, LDL-C, TG, LDL-C/ HDL-C and TC/HDL-C levels. Parameters correlated with NLR are given in Table 3.

\section{Discussion}

Menopause is defined as the permanent discontinuation of menstruation resulting from loss of ovarian follicular activity and 12 months of amenorrhea from the last menstrual period. The final menstrual period (FMP) usually occurs between the ages of 40 and 58 . The average age of menopause is 51 years ${ }^{15,16}$. World Health Organization (WHO) has recommended the use of the following definitions for menopause status categories. Premenopausal period is defined as the entire reproductive period before FMP and the postmenopausal period is defined as dating from the FMP ${ }^{1}$. Stages of reproductive Aging (STRAW) Workshop group divided the adult female life into three broad phases as the reproductive, menopausal transition, and postmenopause. These three phases consist of seven

Table 1. Demographic characteristics and laboratory parameters of two groups

\begin{tabular}{|c|c|c|c|}
\hline Parameters & $\begin{array}{l}\text { Premenopausal group } \\
\qquad(\mathrm{n}=295)\end{array}$ & Postmenopausal group ( $n=153$ ) & $\mathrm{p}$ value \\
\hline Age (years) & $37(33-42)$ & $56(52-62)$ & $<0.001$ \\
\hline Weight (kg) & $68(59-82)$ & $74(67-80)$ & $<0.001$ \\
\hline Height (cm) & $163(158.75-166)$ & $162(15875-165)$ & 0.136 \\
\hline BMI $\left(\mathrm{kg} / \mathrm{m}^{2}\right)$ & $25.91(22.89-30.83)$ & $28,47(25.87-31.21)$ & $<0.001$ \\
\hline Smoking, n (\%) & $76(25.76)$ & $41(26.79)$ & 0.813 \\
\hline $\mathrm{Hb}(\mathrm{g} / \mathrm{dL})$ & $12.40 \pm 1.47$ & $13.09 \pm 1.30$ & $<0.001$ \\
\hline HTC (\%) & $37.08 \pm 3.34$ & $38.85 \pm 3.31$ & $<0.001$ \\
\hline MCV(fL) & $83.6(79.70-87)$ & $84.05(80.87-86.90)$ & 0.564 \\
\hline MCHC (gHb/dL) & $33.29 \pm 2.63$ & $31.29 \pm 8.87$ & $<0.05$ \\
\hline RDW (\%) & $14.02 \pm 2.08$ & $13.80 \pm 1.78$ & 0.261 \\
\hline $\mathrm{FBG}(\mathrm{mg} / \mathrm{dL})$ & $98(92-104)$ & $102(98-107.25)$ & $<0.001$ \\
\hline $\mathrm{TC}(\mathrm{mg} / \mathrm{dL})$ & $190(165-212)$ & $224(197-251.25)$ & $<0.001$ \\
\hline $\mathrm{TG}(\mathrm{mg} / \mathrm{dL})$ & $88(62-126)$ & 129 (96.75-184.75) & $<0.001$ \\
\hline HDL-C (mg/dL) & $55(46-66)$ & $53(42-60.25)$ & 0.069 \\
\hline LDL-C (mg/dL) & $111(87-129)$ & $139(117.75-159.75)$ & $<0.001$ \\
\hline TC/HDL-C & $3.41(2.69-4.21)$ & $4.35(3.61-5.30)$ & $<0.001$ \\
\hline LDL-C/HDL-C & $2(1.44-2.58)$ & $2.78(2.16-3.37)$ & $<0.001$ \\
\hline TG/HDL-C & $1.66(0.96-2.60)$ & 2.47 (1.68-4.27) & $<0.001$ \\
\hline
\end{tabular}


Table 2. Neutrophil-to-lymphocyte ratio and other circulatory blood cell count of two groups

\begin{tabular}{lccc}
\hline Parameters & $\begin{array}{c}\text { Premenopausal } \\
(\mathrm{n}=295)\end{array}$ & Postmenopausal $(\mathrm{n}=153)$ & $\mathrm{p}$ \\
\hline WBC $\left(10^{3} / \mathrm{mm}^{3}\right)$ & $6.58(5.63-7.84)$ & $6.23(5.47-7.51)$ & 0.075 \\
NC $\left(10^{3} / \mathrm{mm}^{3}\right)$ & $3.70(3.04-4.50)$ & $3.63(2.79-4.33)$ & 0.393 \\
LC $\left(10^{3} / \mathrm{mm}^{3}\right)$ & $2.12(1.79-2.52)$ & $2.10(1.70-2.60)$ & 0.624 \\
NLR & $1.77(1.38-2.25)$ & $1.68(1.24-2.07)$ & 0.240 \\
PC $\left(10^{3} / \mathrm{mm}^{3}\right)$ & $261(220-306.75)$ & $257(225.50-288)$ & 0.508 \\
MPV $\left(\mu \mathrm{m}^{3}\right)$ & $10.36 \pm 1.20$ & $10.39 \pm 0.92$ & 0.781 \\
RDW $(\%)$ & $14.02 \pm 2.08$ & $13.80 \pm 1.78$ & 0.284 \\
\hline WBC, white blood cell count; Nc, neutrophil count; Lc, lymphocyte count; NLR, neutrophil to lymphocyte ratio; Pc, platelets count; MPV, main platelet volume; RDW, erythrocyte distribution width. \\
Data are expressed as mean \pm SD or median (interquartil range [lQR] 25th-75th).
\end{tabular}

Table 3. A linear relationship between neutrophil to lymphocyte ratio and the other continuous variables

\begin{tabular}{lcc}
\hline & \multicolumn{2}{c}{ Premenopausal+postmenopausal groups $(\mathrm{n}=448)$} \\
\cline { 2 - 3 } Parameters & $\mathrm{r}$ & $\mathrm{p}$ \\
\hline $\mathrm{FBG}(\mathrm{mg} / \mathrm{dL})$ & -0.114 & 0.016 \\
$\mathrm{Hb}(\mathrm{g} / \mathrm{dL})$ & -0.100 & 0.035 \\
MCHC $(\mathrm{g} / \mathrm{dL})$ & -0.120 & 0.011 \\
RDW $(\%)$ & -0.094 & 0.048 \\
TC $(\mathrm{mg} / \mathrm{dL})$ & -0.109 & 0.021 \\
LDL-C (mg/dL) & -0.093 & 0.049 \\
TG (mg/dL) & -0.109 & 0.021 \\
LDL-C/HDL-C & -0.105 & 0.026 \\
TC/HDL-C & -0.122 & 0.010 \\
\hline FBG, fasting blood glucose; Hb, hemoglobin; MCHC, mean corpuscular hemoglobin concentration; \\
RDW, erythrocyte distribution width; TC, total cholesterol; LDL-C, low-density lipoprotein \\
cholesterol; TG, triglyceride; HDL-C, high density lipoprotein cholesterol. \\
\hline
\end{tabular}

stages centered on the FMP (Stage 0 ). The reproductive phase was divided into Stages $-5,-4$, and -3 corresponding to early, peak, and late, respectively. The menopausal transition phase consisted of Stage -2 (early) and Stage -1 (late), and the postmenopausal

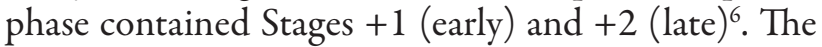
oocytes in the ovaries undergo atresia throughout a women's life cycle, and both the quantity and quality of follicles fall into a sharp decline. Estradiol (E2), the most potent form of the hormone, is predominant before menopause while estrone (E1) is the primary form of menopause. Also, levels of both hormones are considerably lower in postmenopausal period than the premenopausal period ${ }^{17,18}$.

Studies have shown that after menopause, women demonstrate an increased risk of atherosclerotic heart disease $^{17,18}$. It is assumed that menopause-related hormonal changes (decreased level of estrogen, especially E2) are associated with the development of the atherosclerotic cardiovascular disease. Changes in estrogen level may influence inflammatory processes during the menopausal period. It has been shown that menopause causes low grade of systemic inflammation $^{19}$. Several studies demonstrated that chronic low grade inflammation increases the risk of cardiovascular disease $\mathrm{e}^{20}$ Besides, HRT has been shown to reduce serum markes of inflammation and the incidence of cardiovascular disease in postmenopausal women ${ }^{21-23}$.

WBC count refers to the total number of white blood cells in the peripheral blood produced by the bone marrow. It has been related to different cardiovascular risk factors, such as smoking, obesity, and hyperten$\operatorname{sion}^{10,24,25}$. WBC and its fractions including neutrophils and lymphocytes provide an indirect estimate of inflammatory status ${ }^{10,13,26}$.

NLR, the simple ratio obtained from a differential blood cell count, was introduced as a marker to determine inflammation in various disorders such as cardiovascular diseases, malignancies, and diabetes mellitus. It is used as a predictor of adverse cardiovascular outcomes in atherosclerotic heart disease. It was demonstrated that it has an association with the coronary artery disease, pulmonary arterial hypertension, coronary ectasia, arrhythmias, atherosclerotic coronary artery disease, as well as the severity of acute coronary syndromes and the survival after coronary artery disease ${ }^{13,26-30}$.

Several studies have demonstrated that the parameters of blood samples including TC, LDL, and TG levels are increased after menopause ${ }^{4,31}$. However, the effect of menopause on neutrophil, lymphocyte count, and 
NLR is unknown. We found no statistically significant differences between two groups in respect of neutrophil, lymphocyte count and NLR ( $p=0.393, p=0.624$, and $\mathrm{p}=0.240$, respectively).

This research is the first, regarding the investigation of neutrophil, lymphocyte count and NLR in premenopausal and postmenopausal healthy women. Our study has primarily focused on the effects of menopause on neutrophil, lymphocyte count and NLR in healthy women who do not receive an HRT. To the best of our knowledge, no study has investigated the NLR in healty postmenopausal women, for this reason we were unable to compare our results with other studies. Angeli et al. ${ }^{32}$ examined 298 hypertensive postmenopausal women and showed that, in addition to traditional risk factors, neutrophil count identifies hypertensive postmenopausal women at increased risk of cardiovascular disease. In that study, total WBC count did not show any association with cardiovascular events. Another study found that NLR was significantly increased in postmenopausal osteopenic women, which may be used as the indicator of bone loss ${ }^{33}$.

TC, LDL-C and TG levels progressively increase during menopausal period ${ }^{31}$. However, studies examining the influence of menopause on HDL-C have yielded conflicting results. Some concluded that the menopause is not associated with change in HDL-C, while others concluded that menopause is associated with a decline in HDL-C ${ }^{34}$. In our study TC, LDL-C and TG levels were significantly higher in postmenopausal women compared to that of premenopausal women. In contrast, HDL-C levels did not show a statistically significant difference between two groups.

In conclusion, NLR which is an emerging marker of inflammation, is used as a predictor of adverse outcomes in atherosclerotic heart disease. Our results suggest that menopause does not alter NLR in healthy women. For this purpose, the large-scale controlled prospective studies are needed to assess the effect of menopause on humoral and cellular inflammatory markers.

\section{Limitation of the Study}

The main limitations of this study include: single centered/relatively small number of subjects and retrospective design; did not asses the hormone levels; invasive study was not performed to exclude coronary artery disease; and humoral and cellular inflammatory markers were missing from the study data.

\section{Conflict of Interest}

The authors declare no conflict of interest.

\section{References}

1. Utian WH. The International Menopause Society menopauserelated terminology definitions. Climacteric 1999;2:284-6.

2. Kannel WB, Hjortland MC, McNamara PM, et al. Menopause and risk of cardiovascular disease: the Framingham study. Ann Intern Med 1976;85:447-52.

3. Rossi R, Grimaldi T, Origliani G, et al. Menopause and cardiovascular risk. Pathophysiol Haemost Thromb 2002;32:325-8.

4. Matthews KA, Crawford SL, Chae CU, et al. Are changes in cardiovascular disease risk factors in midlife women due to chronological aging or to the menopausal transition? J Am Coll Cardiol 2009;54:2366-73.

5. Gotto AM Jr. Role of C-reactive protein in coronary risk reduction: focus on primary prevention. Am J Cardiol 2007;99:718-25.

6. Mallika V, Goswami B, Rajappa M. Atherosclerosis pathophysiology and the role of novel risk factors: a clinicobiochemical perspective. Angiology 2007;58:513-22.

7. Zhou X, Nicoletti A, Elhage R, et al. Transfer of CD4(+)T cells aggravates atherosclerosis in immunodeficient apolipoprotein $\mathrm{E}$ knockout mice. Circulation 2000;102:2919-22.

8. Sherer Y, Shoenfeld Y. Atherosclerosis: is atherosclerosis a cellular or humoral mediated auto-immune disease? Ann Rheum Dis 2002;61:97-9.

9. Pereira IA, Borba EF. The role of inflammation, humoral and cell mediated autoimmunity in the pathogenesis of atherosclerosis. Swiss Med Wkly 2008;138:534-9.

10. Ates AH, Canpolat U, Yorgun H, et al. Total white blood cell count is associated with the presence, severity and extent of coronary atherosclerosis detected by dual-source multislice computed tomographic coronary angiography. Cardiol J 2011;18:371-7.

11. Libby P, Ridker PM, Maseri A. Inflammation and atherosclerosis. Circulation 2002;105:1135-43.

12. Núñez J, Núñez E, Bodí V, et al. Usefulness of the neutrophil to lymphocyte ratio in predicting long-term mortality in ST segment elevation myocardial infarction. Am J Cardiol 2008;101:747-52.

13. Horne BD, Anderson JL, John JM, et al. Which white blood cell subtypes predict increased cardiovascular risk? J Am Coll Cardiol 2005;45:1638-43.

14. Goswami B, Rajappa M, Singh B, et al. Inflammation and dyslipidaemia: a possible interplay between established risk factors in North Indian males with coronary artery disease. Cardiovasc J Afr 2010;21:103-8.

15. Greendale GA, Lee NP, Arriola ER. The menopause. Lancet 1999;353:571-80.

16. Nelson HD. Menopause. Lancet 2008;371:760-70. 
17. Hale GE, Burger HG. Hormonal changes and biomarkers in late reproductive age, menopausal transition and menopause. Best Pract Res Clin Obstet Gynaecol 2009;23:7-23.

18. Azzawi F, Palacios S. Hormonal changes during menopause. Maturitas 2009;63:135-7.

19. Abu-Taha M, Rius C, Hermenegildo C, Noguera I, CerdaNicolas JM, Issekutz AC, Jose PJ, Cortijo J, Morcillo EJ, Sanz MJ. Menopause and ovariectomy cause a low grade of systemic inflammation that may be prevented by chronic treatment with low doses of estrogen or losartan. J Immunol 2009 15;183(2):1393-402. doi:10 4049/jimmunol 0803157.

20. Willerson JT, Ridker PM. Inflammation as a cardiovascular risk factor. Circulation 2004 1;109(21 Suppl 1): II2-10.

21. Xing D, Nozell S, Chen YF, et al. Estrogen and mechanisms of vascular protection. Arterioscler Thromb Vasc Biol 2009;29:289-95.

22. Clarkson TB, Anthony MS, Morgan TM. Inhibition of postmenopausal atherosclerosis progression: a comparison of the effects of conjugated equine estrogens and soy phytoestrogens. J Clin Endocrinol Metab 2001;86:41-7.

23. Collins P, Rosano G, Casey C, et al. Stramba-Badiale M. Management of cardiovascular risk in the perimenopausal women: a consensus statement of European cardiologists and gynecologists. Climacteric 2007;10:508-26.

24. Lind L. Circulating markers of inflammation and atherosclerosis. Atherosclerosis 2003;169:203-14.

25. Rasouli M, Nesarhosseini V, Kiasari AM, et al. The multiplicative interactions of leukocyte counts with some other risk factors enhance the prognostic value for coronary artery disease. Cardiol J 2011;18:246-53.
26. Madjid M, Awan I, Willerson JT, et al. Leukocyte count and coronary heart disease: implications for risk assessment. J Am Coll Cardiol 2004;44:1945-56.

27. Gibson PH, Cuthbertson BH, Croal BL, et al. Usefulness of neutrophil/lymphocyte ratio as predictor of new-onset atrial fibrillation after coronary artery bypass grafting. Am J Cardiol 2010;105:186-91.

28. Işık T, Ayhan E, Uyarel H, et al. Association of neutrophil to lymphocyte ratio with presence of isolated coronary artery ectasia. Turk Kardiyol Dern Ars 2013;41:123-30.

29. Erayman A, Sen N. Neutrophil-lymphocyte ratio and C-reactive protein may be correlated in patients with coronary artery ectasia. Angiology 2014;65:84-85.

30. Margolis KL, Manson JE, Greenland P, et al. Leukocyte count as a predictor of cardiovascular events and mortality in postmenopausal women. Arch Intern Med 2005;165:500-8.

31. de Aloysio D, Gambacciani M, Meschia M, et al. The effect of menopause on blood lipid and lipoprotein levels. Atherosclerosis 1999; 147:147-53.

32. Angeli F, Angeli E, Ambrosio G, et al. Neutrophil count for the identification of postmenopausal hypertensive women at increased cardiovascular risk. Obstet Gynecol 2010;115:695703.

33. Liu W, Huang Z, Tang S, Wei S, Zhang Z1. An evaluation of homocysteine, C-reactive protein, lipid levels, neutrophils to lymphocyte ratio in postmenopausal osteopenic women. Gynecol Endocrinol 2016 Jan 8:1-3.

34. Stevenson JC, Crook D, Godsland IF. Influence of age and menopause on serum lipids and lipoproteins in healthy women. Atherosclerosis 1993;98:83-90. 